\title{
Adenosine A, Receptor Agonists Block the Neuropathological Changes in Rat Retrosplenial Cortex after Administration of the NMDA Receptor Antagonist Dizocilpine
}

\author{
Naoe Okamura', Kenji Hashimoto*,', Eiji Shimizu', Chikara Kumakiri', Naoya Komatsu' and Masaomi lyo' \\ 'Department of Psychiatry, Graduate School of Medicine, Chiba University, Chiba 260-8670, Japan
}

\begin{abstract}
Noncompetitive N-methyl-D-aspartate (NMDA) receptor antagonist dizocilpine ((+)-MK-80I) is known to induce neurotoxicity in rat retrosplenial cortex after systemic administration. The present study was undertaken to examine the effects of adenosine $A_{1}$ receptor agonists on the neurotoxicity in rat retrosplenial cortex after administration of dizocilpine. Pretreatment with adenosine $A_{1}$ receptor agonists, 2-chloro- $N^{6}$-cyclopentyladenosine (CCPA) $\left(0.1,0.3,1\right.$, or $3 \mathrm{mg} / \mathrm{kg}$, intraperitoneally (i.p.)), or $N^{6}$-cyclopentyladenosine (CPA) ( 1 , 3, or $10 \mathrm{mg} / \mathrm{kg}$, i.p.), attenuated neurotoxicity by dizocilpine $(0.5 \mathrm{mg} / \mathrm{kg}$, i.p), in a dose-dependent manner. Coadministration with

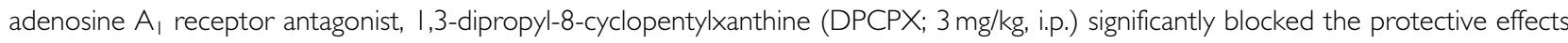
of CCPA for dizocilpine-induced neurotoxicity. Furthermore, pretreatment with CCPA (3 mg/kg) attenuated significantly the dizocilpineinduced expression of HSP-70 protein, which is known as a sensitive marker of reversible neuronal damage, and coadministration with DPCPX (3 mg/ $/ \mathrm{kg}$ ) blocked the inhibitory effects of CCPA for marked expression of HSP-70 protein by administration of dizocilpine. Moreover, pretreatment with CCPA ( $3 \mathrm{mg} / \mathrm{kg}$, i.p.) significantly suppressed the increase of extracellular acetylcholine (ACh) levels in the retrosplenial cortex by administration of dizocilpine $(0.5 \mathrm{mg} / \mathrm{kg})$. In contrast, local perfusion of CCPA ( $\mu \mathrm{M})$ into the retrosplenial cortex via the dialysis probe did not alter the ACh levels by administration of dizocilpine $(0.5 \mathrm{mg} / \mathrm{kg})$, suggesting that the locus of action of CCPA is not in the retrosplenial cortex. These findings suggest that adenosine $A_{1}$ receptors agonists could protect against neuropathological changes in rat retrosplenial cortex after administration of the NMDA receptor antagonist dizocilpine.

Neuropsychopharmacology (2004) 29, 544-550, advance online publication, 5 November 2003; doi: I0. I038/sj.npp. I 30035 I
\end{abstract}

Keywords: adenosine; glutamate; adenosine A, receptors; NMDA receptors; retrosplenial cortex; schizophrenia

\section{INTRODUCTION}

Several lines of evidence have suggested that a dysfunction in glutamatergic neurotransmission via the $N$-methyl-Daspartate (NMDA) receptors might be involved in the pathophysiology of schizophrenia (Coyle, 1996; Javitt and Zukin, 1991; Olney and Farber, 1995; Tamminga, 1998). This hypothesis evolves from clinical findings that noncompetitive NMDA receptor antagonists such as phencyclidine (PCP) and its congener ketamine induce a schizophrenia-like psychosis representing negative and positive symptoms as well as cognitive dysfunction in humans (Javitt and Zukin, 1991; Krystal et al, 1994; Luby et al, 1959). Rodents treated with NMDA receptor

\footnotetext{
*Correspondence: Dr K Hashimoto, Department of Psychiatry (K2), Graduate School of Medicine, Chiba University, I-8-I Inohana, Chiba 260-8670, Japan, Tel: +81 43226 2147, Fax: + 8143226 2150, E-mail: hashimoto@faculty.chiba-u.jp

Received I4 May 2003; revised 08 October 2003; accepted 09 October 2003

Online publication: 10 October 2003 at http://www.acnp.org/citations/ Npp I01003032|4/default.pdf
}

antagonists have been widely used in preclinical research on the neurobiology of schizophrenia (Gainetdinov et al, 2001). As part of this research, it has been demonstrated that NMDA receptor antagonists such as PCP and dizocilpine $((+)$-MK-801) cause neuropathological changes in the rat retrosplenial cortex (Olney and Farber, 1995). Interestingly, it has been reported that the antipsychotic drugs clozapine and zotepine, but not haloperidol, block dizocilpine-induced neuropathological changes in the rat retrosplenial cortex at therapeutic doses (Farber et al, 1996; Fujimura et al, 2000; Hashimoto et al, 2000; Okamura et al, 2003). Therefore, determination of the potential to reverse dizocilpine-induced neuropathological changes in rat retrosplenial cortex may provide a beneficial model of screening for clozapine-like antipsychotic drugs (Morimoto et al, 2002; Olney and Farber, 1995; Olney et al, 1999; Sharp et al, 2001).

Adenosine receptors can be divided into four subtypes $\left(A_{1}, A_{2 A}, A_{2 B}\right.$, and $A_{3}$ ) (Fredholm, 1995; Fredholm et al, 2001). Adenosine $A_{1}$ and $A_{2 A}$ receptors occur ubiquitously in the brain, and these receptors play a role in a variety of effects, for example, as anticonvulsants, anti-nociceptives, 
sedatives, muscle relaxants, and inhibitors of opiate withdrawal in morphine-dependent mice (Fredholm, 1995; Stone, 1991). Adenosine $A_{1}$ receptors play an important part in both the neuromodulatory role at the synaptic level and the homeostatic role of controlling the cell metabolism and ionic current (Cunha, 2001). In addition to their neuroprotective effect in ischemic models (Von Lubitz et al, 1999; Jacobson et al, 1996), it is reported that adenosine affects the behavioral and physiological effects of NMDA receptor antagonists. Adenosine $\mathrm{A}_{1}$ receptor agonists decreased the electroencephalographic abnormalities induced by dizocilpine in rats (Popoli et al, 1997), and blocked the abnormality of prepulse inhibition of acoustic startle response induced by PCP in rats (Browne and Welch, 1982; Sills et al, 1999).

The heat shock or stress genes are induced by a wide variety of stimuli, including heat, ischemic stress, calcium ionophores, and certain toxins. Heat shock proteins may play important roles in cellular repair and/or protective mechanisms (Brown, 1995). Heat shock protein HSP-70, which is known as a sensitive marker of reversible neuronal damage, was induced in the retrosplenial cortex of the rat brain after administration of noncompetitive NMDA receptor antagonists such as dizocilpine, PCP, ketamine, and memantine (Sharp et al, 1991, 2001; Hashimoto et al, 1996, 1997; Tomitaka et al, 1996, 2000). Furthermore, it has been reported that the NMDA receptor hypofunction state induced by administering NMDA receptor antagonist dizocilpine causes excessive release of acetylcholine (ACh) in retrosplenial cortex, and that $\gamma$-aminobutyric acid $\mathrm{A}$ $\left(\mathrm{GABA}_{\mathrm{A}}\right)$ agonists or $\alpha_{2}$-adrenergic agonists prevent such release (Kim et al, 1999). Studying the circuitry and receptor mechanisms of neurotoxicity of dizocilpine, Farber et al (2002) hypothesized that dizocilpine-induced neurotoxicity involves increased glutamatergic and cholinergic activity at the retrosplenial cortex, and it is reasonable to also hypothesize that activation of adenosine $A_{1}$ receptors, which inhibit the release of neurotransmitters including $\mathrm{ACh}$, would have a neuroprotective effect in this model.

Given these previous findings, the present study was undertaken to examine the effect of the adenosine $A_{1}$ receptor agonists CCPA and CPA on the neurotoxicity and expression of HSP-70 protein in rat retrosplenial cortex after administration of dizocilpine. We also used in vivo microdialysis methods to study the effects of adenosine $A_{1}$ receptor agonist on dizocilpine-induced increase of extracellular ACh levels in retrosplenial cortex.

\section{METHODS}

\section{Animals}

Female Sprague-Dawley rats (SLC, Hamamatsu, Shizuoka, Japan, $10-11$ weeks old, $190-245 \mathrm{~g}$ ) were housed separately under a 12-h light/12-h dark cycle with free access to food and water. We used female rats for all experiments in this study, as female rats are known to be more sensitive than male rats to the neurotoxic effects of NMDA receptor antagonists (Farber et al, 1995; Fix et al, 1995; Matsuki et al, 2001). All experiments were carried out in accordance with the Guide for Animal Experimentation, Chiba University Graduate School of Medicine.

\section{Drugs}

The following drugs were purchased from the following sources: dizocilpine maleate, 2-chloro- $N^{6}$-cyclopentyladenosine (CCPA), $N^{6}$-cyclopentyladenosine (CPA), 1,3-dipropyl-8-cyclopentylxanthine (DPCPX) (Sigma-RBI, St Louis, MO, USA), and 2-p-(2-carboxyethyl)phenethylamino- $5^{\prime}-\mathrm{N}$ ethylcarboxamidoadenosine (CGS 21680) (Tocris Cookson Ltd., Bristol, UK). Other chemicals of analytical grade were purchased commercially.

\section{Drug Treatment}

Animals were injected intraperitoneally (i.p.) with vehicle $(0.15 \%$ Tween $80 ; 2 \mathrm{ml} / \mathrm{kg})$, CCPA $(0.1,0.3,1$, or $3 \mathrm{mg} / \mathrm{kg})$, CPA $(1,3$, or $10 \mathrm{mg} / \mathrm{kg})$, CGS $21680(1 \mathrm{mg} / \mathrm{kg})$, or CCPA (1 or $3 \mathrm{mg} / \mathrm{kg}$ ) plus DPCPX (1 or $3 \mathrm{mg} / \mathrm{kg}$ ). After $15 \mathrm{~min}$, the animals were injected i.p. with vehicle (distilled water; $1 \mathrm{ml} /$ $\mathrm{kg}$ ) or dizocilpine $(0.5 \mathrm{mg} / \mathrm{kg})$.

\section{Neuropathology}

At $4 \mathrm{~h}$ after administration of dizocilpine, the animals were deeply anesthetized with sodium pentobarbital $(50 \mathrm{mg} / \mathrm{kg}$, i.p.). After $10 \mathrm{~min}$, the animals were transcardially perfused with $100 \mathrm{ml}$ of isotonic saline, followed by $400 \mathrm{ml}$ of ice-cold $4 \%$ paraformaldehyde in $0.1 \mathrm{M}$ phosphate buffer ( $\mathrm{pH} 7.4$ ). Subsequently, the brain was removed, processed by graded ethanol dehydration, embedded in paraffin, then sectioned into $4-\mu \mathrm{m}$-thick coronal slices, and stained with hematoxylin and eosin. We used the brain level of bregma $-5.80 \mathrm{~mm}$ from the atlas of the rat brain (Paxinos and Watson, 1998). We counted the number of vacuolized neurons in layers III and IV of the retrosplenial cortex of each side of the brain and averaged the number of vacuolized neurons for each subject from two slides per subject. Counting was performed blind with respect to the treatment group.

\section{Immunohistochemistry}

HSP-70 immunohistochemistry was performed using a Vectastain ${ }^{\circledR}$ Elite ABC kit (Vector Laboratories, Burlingame, CA, USA), as described previously (Hashimoto et al, 1997). At $24 \mathrm{~h}$ after administration of dizocilpine $(0.5 \mathrm{mg} /$ $\mathrm{kg}$ ), the animals were deeply anesthetized with sodium pentobarbital $(50 \mathrm{mg} / \mathrm{kg}$, i.p.). After $10 \mathrm{~min}$, the animals were transcardially perfused with $100 \mathrm{ml}$ of isotonic saline, followed by $400 \mathrm{ml}$ of ice-cold $4 \%$ paraformaldehyde in $0.1 \mathrm{M}$ phosphate buffer ( $\mathrm{pH}$ 7.4). The brain was removed and postfixed overnight at $4{ }^{\circ} \mathrm{C}$ in the same fixative, and then $50-\mu \mathrm{m}$-thick coronal sections of brains were cut in the ice-cold $0.01 \mathrm{M}$ phosphate buffer saline (PBS; pH 7.4) using a vibrating blade microtome (VT1000S, Leica Microsystems Nussloch GmbH, Nussloch, Germany). The slices were washed twice in ice-cold $0.01 \mathrm{M}$ PBS. Free-floating sections were placed in $0.01 \mathrm{M}$ PBS buffer containing $2 \%$ horse serum, $0.2 \%$ Triton X-100, and $0.1 \%$ bovine serum albumin (HS-PBST) for $1 \mathrm{~h}$ at room temperature. The samples were incubated for $48 \mathrm{~h}$ at $4^{\circ} \mathrm{C}$ with a primary antibody to HSP-70 (Stressgen Biotechnologies Corp., Victoria, BC, Canada) diluted 1/1000 in HS-PBST. The sections were washed twice 
in PBS, incubated for $1 \mathrm{~h}$ with a second antibody (biotinylated horse anti-rabbit immunoglobulin G; diluted $1 / 200$ ), and then incubated in an avidin-biotinylated horseradish peroxidase solution prepared from a kit for $1 \mathrm{~h}$ at room temperature. The sections were washed twice in icecold PBS, and an antibody reaction was developed with $3,3^{\prime}$ diaminobenzidine $(0.015 \%)$ and $0.001 \%$ hydrogen peroxide in $50 \mathrm{mM}$ Tris- $\mathrm{HCl}(\mathrm{pH}$ 7.4). Following several rinses in PBS, sections were mounted on gelatinized slides, dehydrated through an ethanol gradient and cleared in xylene, and coverslipped with Permount ${ }^{\circledR}$ (Fisher Scientific, Fair Lawn, NJ, USA). We counted the number of neurons expressing HSP-70 immunoreactivity in the section containing layers III- $\mathrm{V}$ of the retrosplenial cortex, and averaged the number of HSP-70 immunoreactive neurons from two sections for each subject. Counting was performed blind with respect to the treatment group.

\section{In vivo Microdialysis}

Each rat was anesthetized with sodium pentobarbital $(50 \mathrm{mg} / \mathrm{kg}$, i.p.) and placed in a stereotaxic frame. A concentric I-type dialysis probe $(0.22 \mathrm{~mm}$ diameter; $1.5 \mathrm{~mm}$ exposed membrane; Eicom Co., Kyoto, Japan) was implanted into the retrosplenial cortex $(A=5.8 \mathrm{~mm}$, $L=0.5 \mathrm{~mm}, D=1.5$ ) relative to the bregma. The perfusion experiments were started $36-48 \mathrm{~h}$ after the rats had recovered from anesthesia. The perfusion rate was always $2 \mu \mathrm{l} / \mathrm{min}$, using modified Ringer's solution composed of $\mathrm{Na}^{+} 147 \mathrm{mM}, \mathrm{K}^{+} 4 \mathrm{mM}, \mathrm{Ca}^{2+} 2.3 \mathrm{mM}$, and $\mathrm{Cl}^{-} 155.6 \mathrm{mM}$ containing $2 \times 10^{-4} \mathrm{M}$ eserine sulfate. Dialysate was collected every $30 \mathrm{~min}$ and stored at $-80^{\circ} \mathrm{C}$.

The high-performance liquid chromatography (HPLC) system used for the determination of ACh was equipped with an electrochemical detector system (ECD-300, Eicom Co., Kyoto, Japan). The mobile phase contained $0.1 \mathrm{M}$ $\mathrm{Na}_{2} \mathrm{HPO}_{4}$ and $65 \mathrm{mg} / \mathrm{ml}$ tetramethylammonium chloride, $200 \mathrm{mg} / \mathrm{l}$ sodium 1-decanesulfonate, $\mathrm{pH} 8.5$ (adjusted with phosphoric acid), and a flow rate of $0.6 \mathrm{ml} / \mathrm{min}$. Samples were injected manually into an analytical column (EICOMPAK AC-GEL, $150 \mathrm{~mm} \times 4.6 \mathrm{~mm}$ diameter; Eicom). A postcolumn enzyme reactor (AC-ENZYMPAK, $5 \mathrm{~mm} \times$ $4.6 \mathrm{~mm}$ diameter; Eicom) containing choline oxidase and acetylcholinesterase was used to convert ACh and choline to hydrogen peroxide before detection across a platinum electrode (WE-PT; Eicom) held at $450 \mathrm{mV}$ relative to a reference electrode (RE-100; Eicom).

\section{Statistical Analysis}

The differences between multiple groups of neuronal vacuolization and immunohistochemistry were examined by means of one-way analysis of variance (ANOVA), followed by Bonferroni/Dunn's post hoc test. The criteria for significance were ${ }^{*} p<0.05,{ }^{*} p<0.01$. The data were presented as the mean \pm standard error of mean (SEM). The $\mathrm{ED}_{50}$ values for neuronal vacuolization were calculated by conventional graphical techniques by means of the iterative nonlinear least-squares method.

For data analysis of in vivo microdialysis, ACh output was expressed as a percentage of basal concentration. For each rat, a basal ACh concentration was determined by obtaining the mean value for the first three samples collected before administration of a drug. The extracellular ACh concentration of each sample was divided by the calculated basal concentration and multiplied by 100 to obtain a percentage value. The differences between the control group and the drug-treated group were evaluated by two-way ANOVA seeking a significant interaction between treatment condition and time. Statistical comparison at each measurement time between groups was made by the Fisher's protected least significant difference (Fisher's PLSD) following oneway ANOVA. The criteria for significance were ${ }^{\star} p<0.05$, ${ }^{* *} p<0.01$ at the corresponding time point. The data were presented as the mean \pm SEM.

\section{RESULTS}

Behavioral responses occurred within $5 \mathrm{~min}$ after administration of dizocilpine $(0.5 \mathrm{mg} / \mathrm{kg})$. In accordance with previous reports (Koek et al, 1988; Tricklebank et al, 1989), a single administration of dizocilpine $(0.5 \mathrm{mg} / \mathrm{kg})$ to female rats produced head weaving and biting in a stationary posture, and increased locomotion within 15 min of injection; rats then exhibited occasional movements in the flat-body posture until the end of the experiment ( $4 \mathrm{~h}$ after injection). Pretreatment with CCPA $(0.1,0.3,1$, or $3 \mathrm{mg} / \mathrm{kg})$ or CPA $(1,3$, or $10 \mathrm{mg} / \mathrm{kg})$ did not alter the abnormal behavioral changes induced in rats by dizocilpine, although we did not evaluate it quantitatively.

The administration of dizocilpine $(0.5 \mathrm{mg} / \mathrm{kg}$, i.p.) caused neuronal vacuolization in layers III-IV of the retrosplenial cortex of the rat brain $4 \mathrm{~h}$ after administration. One-way ANOVA showed significant differences among groups $(\mathrm{F}=19.43[4,39], p<0.0001$; Figure 1$)$, and pretreatment with CCPA $(0.1,0.3,1$, or $3 \mathrm{mg} / \mathrm{kg})$ decreased the number of vacuolized neurons in the retrosplenial cortex after administration of dizocilpine, in a dose-dependent manner (Figure 1). The $\mathrm{ED}_{50}$ value of CCPA was $0.72 \mathrm{mg} / \mathrm{kg}(95 \%$ confidential limits; $0.59-0.88 \mathrm{mg} / \mathrm{kg}$ ). Another selective

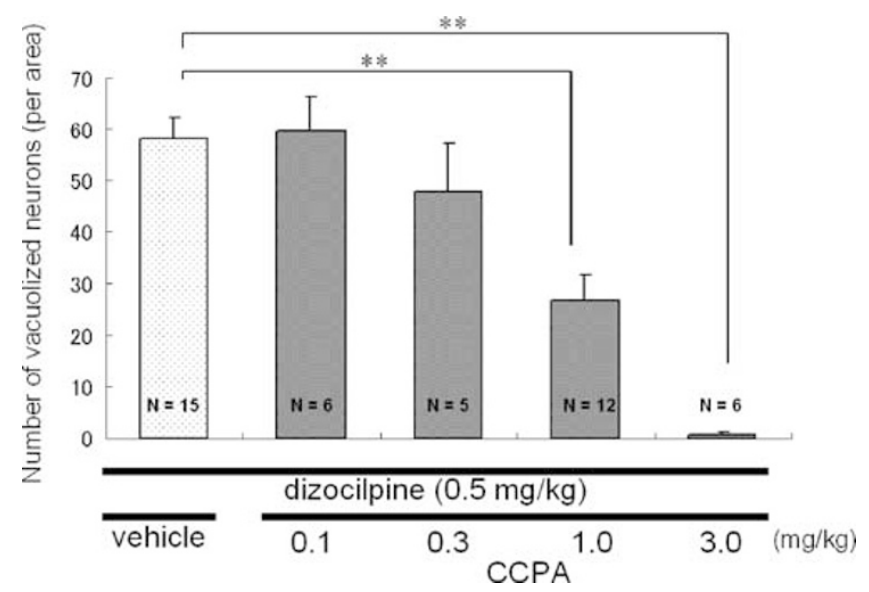

Figure I Effects of pretreatment with CCPA on dizocilpine-induced neurotoxicity in the rat etrosplenial cortex. At $15 \mathrm{~min}$ after i.p. administration of vehicle $(2 \mathrm{ml} / \mathrm{kg})$ or CCPA $(0.1,0.3, \quad$, or $3 \mathrm{mg} / \mathrm{kg})$, dizocilpine $(0.5 \mathrm{mg} / \mathrm{kg})$ was administered to rats. The number of vacuolized neurons in the rat retrosplenial cortex was counted $4 \mathrm{~h}$ after administration of dizocilpine. Each value is the mean \pm SEM of $5-15$ rats. $* * * 20.01$ as compared with the vehicle-treated group. 
adenosine $A_{1}$ receptor agonist, $\mathrm{CPA}(1,3$, or $10 \mathrm{mg} / \mathrm{kg})$, also decreased the number of vacuolized neurons after administration of dizocilpine. One-way ANOVA showed significant differences among groups $(\mathrm{F}=17.68[3,20], p<0.0001$; Figure 2), and its effect in a dose-dependent manner. The $\mathrm{ED}_{50}$ value of CPA was $1.56 \mathrm{mg} / \mathrm{kg}$ (95\% confidential limits; $1.23-1.91 \mathrm{mg} / \mathrm{kg}$ ).

Coadministration of DPCPX (1 or $3 \mathrm{mg} / \mathrm{kg}$ ) with CCPA $(3 \mathrm{mg} / \mathrm{kg})$ significantly attenuated the protective effect of CCPA, and one-way ANOVA showed significant differences among the four groups $(\mathrm{F}=28.63[3,29]), \quad p<0.0001$; Figure 3). In addition, administration of the vehicle $(2 \mathrm{ml} /$ $\mathrm{kg})$, CCPA $(1 \mathrm{mg} / \mathrm{kg})$, or DPCPX $(1 \mathrm{mg} / \mathrm{kg})$ alone did not

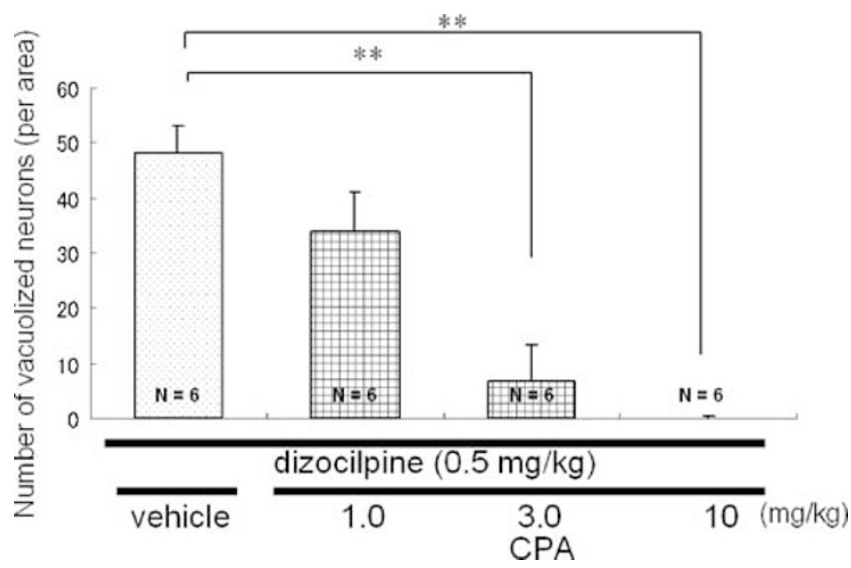

Figure 2 Effects of pretreatment with CPA on dizocilpine-induced neurotoxicity in the rat retrosplenial cortex. At $15 \mathrm{~min}$ after i.p. administration of vehicle $(2 \mathrm{ml} / \mathrm{kg})$, CPA $(\mathrm{I}, 3$, or $10 \mathrm{mg} / \mathrm{kg})$, the rats were administrated dizocilpine $(0.5 \mathrm{mg} / \mathrm{kg}$, i.p.) and killed $4 \mathrm{~h}$ after administration of dizocilpine. The number of vacuolized neurons in the rat retrosplenial cortex was counted. Each value is the mean \pm SEM of six rats. ${ }^{*} * p<0.01$ as compared with the vehicle-treated group.

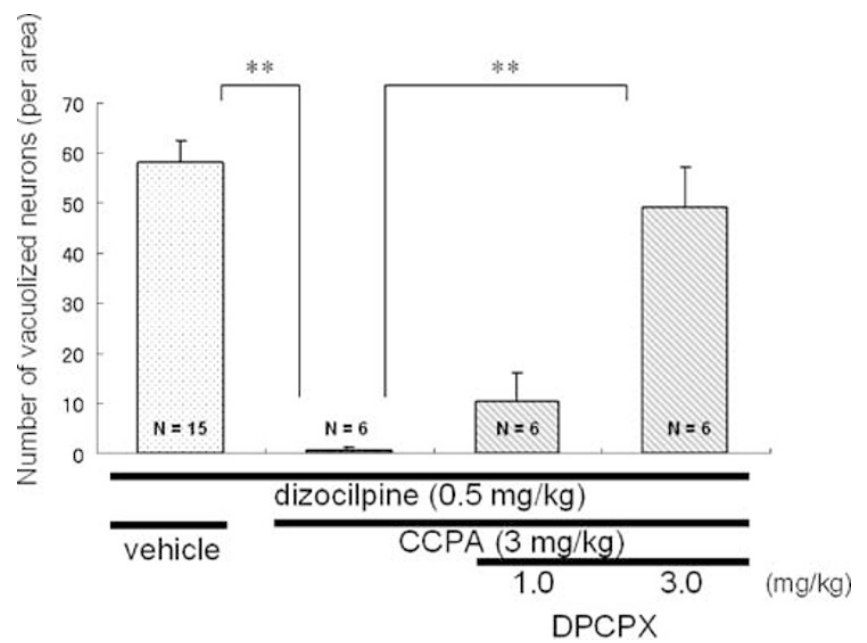

Figure 3 Effects of DPCPX on the protective effects of CCPA for dizocilpine-induced neurotoxicity in the rat retrosplenial cortex. At 15 min after i.p. administration of vehicle $(2 \mathrm{ml} / \mathrm{kg})$, CCPA $(3 \mathrm{mg} / \mathrm{kg})$, or CCPA $(3 \mathrm{mg} / \mathrm{kg}$ ) plus DPCPX (I or $3 \mathrm{mg} / \mathrm{kg}$ ), the rats were administrated dizocilpine $(0.5 \mathrm{mg} / \mathrm{kg}$, i.p.) and killed $4 \mathrm{~h}$ after administration of dizocilpine. The number of vacuolized neurons in the rat retrosplenial cortex was counted. Each value is the mean \pm SEM of six or 15 rats. $* * *<<0.01$ as compared with the CCPA-treated group. produce neuronal vacuolization. Pretreatment with adenosine $A_{2 \mathrm{~A}}$ receptor agonist CGS $21680(1 \mathrm{mg} / \mathrm{kg})$ did not significantly alter the number of neurons vacuolized after administration of dizocilpine $(0.5 \mathrm{mg} / \mathrm{kg})$.
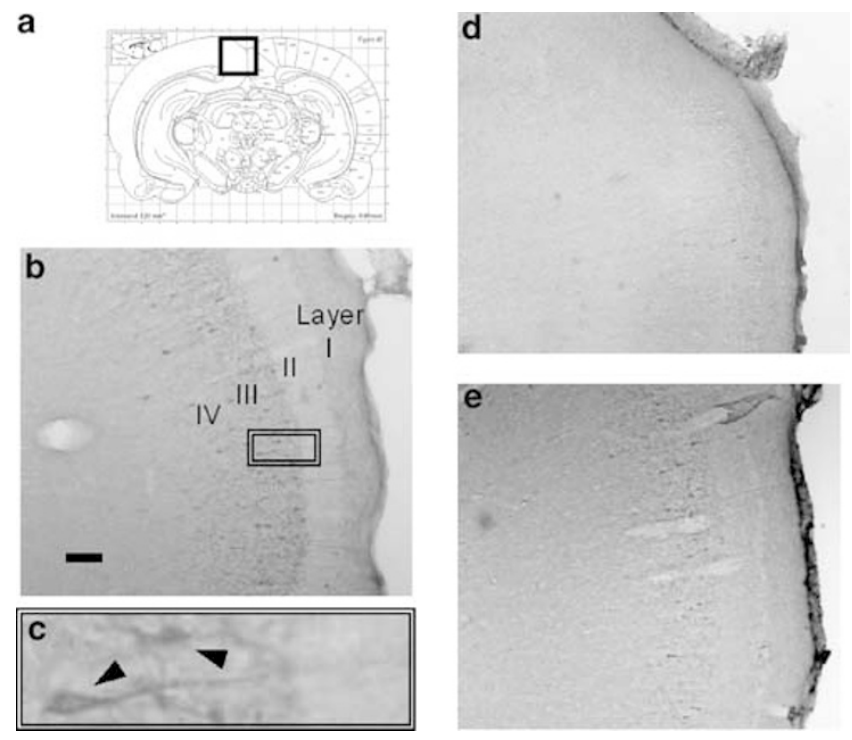

Figure 4 Effects of adenosine $A_{1}$ receptor agonist CCPA and antagonist DPCPX in the expression of HSP-70 in the rat retrosplenial cortex after administration of dizocilpine. At 15 min after administration of vehicle $(2 \mathrm{ml} /$ $\mathrm{kg}$, i.p.), CCPA (3 mg/kg, i.p.), or CCPA (3 mg/kg, i.p.) plus DPCPX (I or $3 \mathrm{mg} / \mathrm{kg}$, i.p.), the rats were administrated dizocilpine $(0.5 \mathrm{mg} / \mathrm{kg}$, i.p.). The HSP-70 immunohistochemistry in the rat brain was performed $24 \mathrm{~h}$ after administration of vehicle or dizocilpine. The HSP-70 immunohistochemistry in the rat brain was performed $24 \mathrm{~h}$ after administration of vehicle or dizocilpine. (a) Drawing of a coronal section of a rat brain including the retrosplenial cortex (Paxinos and Watson, 1998). (b) Vehicle + dizocilpine, (c) A magnified view of (b) (arrowhead shows HSP-70 positive neurons), (d) CCPA + dizocilpine, (e) CCPA and DPCPX+dizocilpine. Scale bar: $100 \mu \mathrm{m}$.

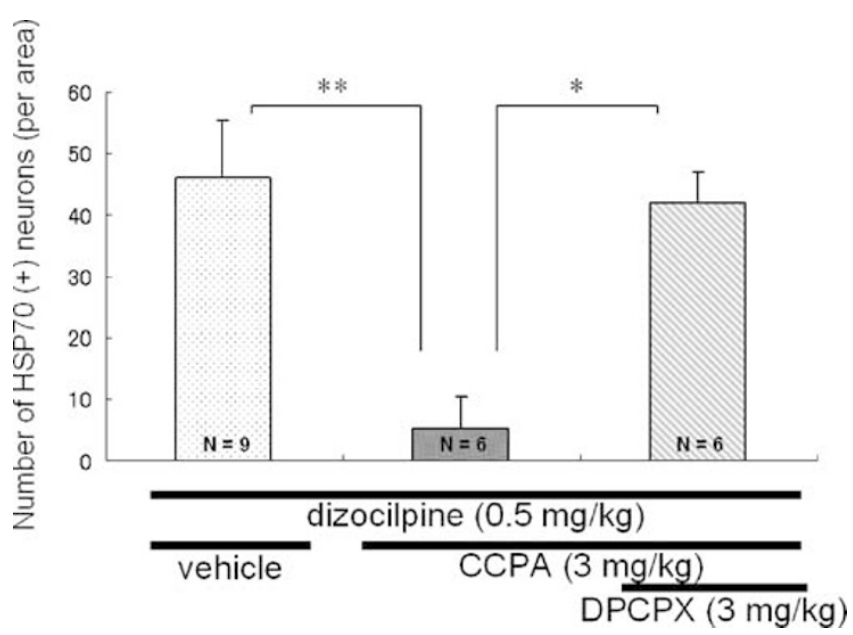

Figure 5 Effects of adenosine $A$, receptor agonist CCPA and antagonist DPCPX in the expression of HSP-70 in the rat retrosplenial cortex after administration of dizocilpine. At 15 min after i.p. administration of vehicle $(2 \mathrm{ml} / \mathrm{kg})$, CCPA $(3 \mathrm{mg} / \mathrm{kg})$, or CCPA $(3 \mathrm{mg} / \mathrm{kg})$ plus DPCPX $(3 \mathrm{mg} / \mathrm{kg})$, dizocilpine $(0.5 \mathrm{mg} / \mathrm{kg})$ was administered to rats. The number of HSP-70 immunoreactive neurons in the rat retrosplenial cortex was counted $24 \mathrm{~h}$ after administration of dizocilpine. Each value is the mean \pm SEM of six or nine rats. $* p<0.05, * * p<0.01$ as compared with the CCPA-treated group. 
The administration of dizocilpine $(0.5 \mathrm{mg} / \mathrm{kg})$ increased the expression of HSP-70 protein in layers III-V of the retrosplenial cortex of the rat brain (Figures 4 and 5). Pretreatment with CCPA $(3 \mathrm{mg} / \mathrm{kg})$ significantly inhibited the marked expression of HSP-70 protein by dizocilpine (Figure 5). One-way ANOVA showed significant differences among groups $(\mathrm{F}=7.74[2,18], p=0.0038)$, and pretreatment with CCPA $(3 \mathrm{mg} / \mathrm{kg})$ significantly inhibited the expression of HSP-70 protein in the retrosplenial cortex by dizocilpine (Figure 5). Furthermore, coadministration of DPCPX $(3 \mathrm{mg} / \mathrm{kg})$ with CCPA $(3 \mathrm{mg} / \mathrm{kg})$ significantly attenuated the protective effect of CCPA on the expression of HSP-70 protein by dizocilpine (Figures 4 and 5).

In vivo microdialysis study indicated that the administration of dizocilpine $(0.5 \mathrm{mg} / \mathrm{kg})$ increased significantly the extracellular levels of $\mathrm{ACh}$ in rat retrosplenial cortex, as previously reported (Kim et al, 1999). Pretreatment with CCPA (1 or $3 \mathrm{mg} / \mathrm{kg}$, i.p.) significantly suppressed the increase of ACh by dizocilpine, and there was a tendency of dose dependence (Figure 6). Next, we examined the effects of direct application of CCPA $(1 \mu \mathrm{M})$ into the retrosplenial cortex on the increase of ACh levels after systemic administration of dizocilpine $(0.5 \mathrm{mg} / \mathrm{kg})$. Perfusion of CCPA $(1 \mu \mathrm{M})$ into the retrosplenial cortex via the dialysis probe did not alter the extracellular levels of ACh in retrosplenial cortex after administration of dizocilpine (Figure 7).

\section{DISCUSSION}

The major findings of the present study are that the adenosine $A_{1}$ receptor agonist CCPA significantly decreased the number of vacuolized neurons and neurons expressing HSP-70 immunoreactivity in rat retrosplenial cortex in-

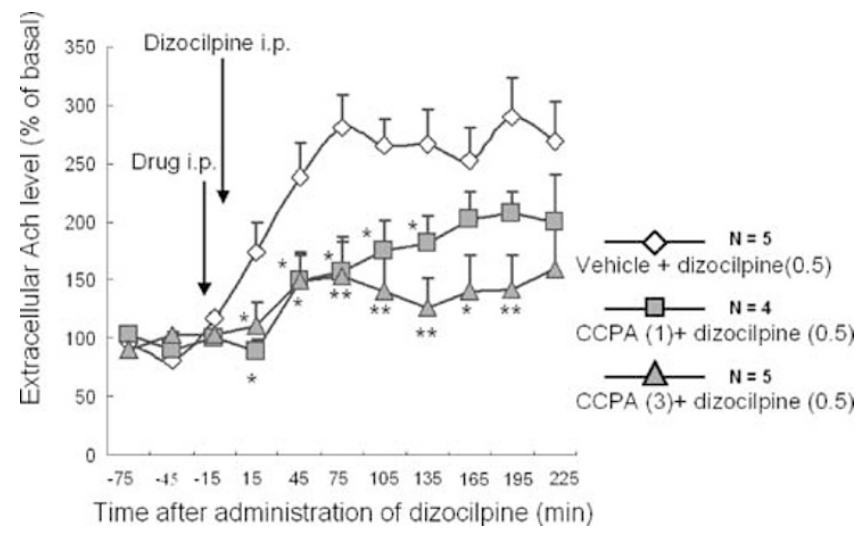

Figure 6 Effects of systemic administration of CCPA on increase of extracellular ACh levels in the retrosplenial cortex after administration of dizocilpine. Dialysate samples were collected every $30 \mathrm{~min}$. Levels of ACh were calculated as described in the Methods section, and values are expressed as the percentage of basal ACh concentration (mean \pm SEM of four or five rats). At $15 \mathrm{~min}$ after i.p. administration of CCPA (I or $3 \mathrm{mg} / \mathrm{kg}$, i.p.) or vehicle $(2 \mathrm{ml} / \mathrm{kg}$, i.p.), dizocilpine $(0.5 \mathrm{mg} / \mathrm{kg}$, i.p.) was administrated to rats. The systemic administration of CCPA resulted in a significant decrease in ACh concentration in the retrosplenial cortex as compared to that of the control group ( $F=3.764[2,20], p<0.000 \mathrm{I})$. $* p<0.05$, *** $p<0.01$ compared to the vehicle-treated group at the corresponding time point

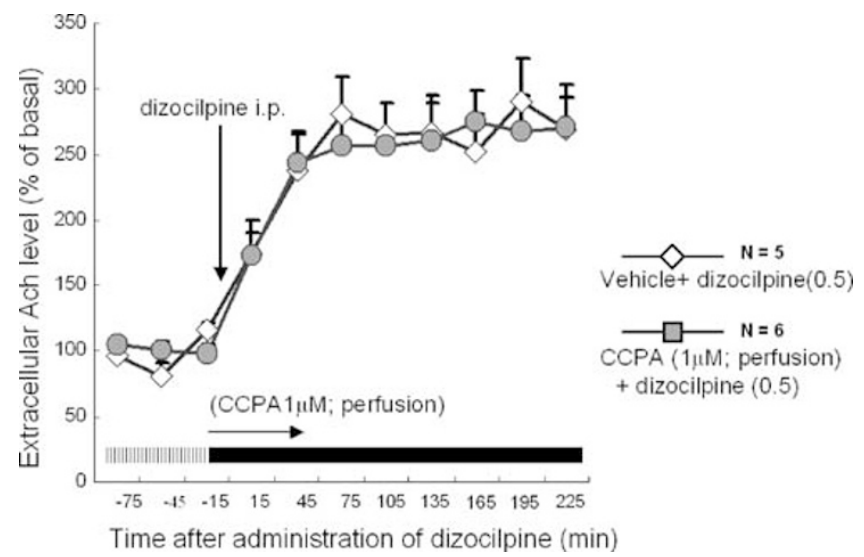

Figure 7 Effects of a local perfusion of CCPA on dizocilpine-induced elevation of extracellular ACh levels in the retrosplenial cortex. Dialysate samples were collected every $30 \mathrm{~min}$. Levels of ACh were calculated as described in the Methods section, and values are expressed as percentage of basal ACh concentration (mean + SEM of 5 rats). At 30 minutes after starting a local perfusion of CCPA $(I \mu \mathrm{M})$ directly into the retrosplenial cortex, dizocilpine $(0.5 \mathrm{mg} / \mathrm{kg}$, i.p.) was administrated to rats. The local perfusion of CCPA resulted in no significant change in ACh concentration in the retrosplenial cortex as compared to that of the control group $(F=0.559[\mathrm{I}, \mathrm{I0}], \mathrm{p}=0.843)$

duced by dizocilpine, and that coadministration with the adenosine $A_{1}$ receptor antagonist DPCPX could reverse the protective effects of CCPA for neuropathological damages and HSP-70 expression. Furthermore, CPA, another selective adenosine $A_{1}$ receptor agonist, was also found to decrease the number of vacuolized neurons, and the $\mathrm{ED}_{50}$ values of CPA were higher than those of CCPA, which is also the case for their respective $K_{\mathrm{i}}$ values of adenosine $\mathrm{A}_{1}$ receptors (Lohse et al, 1988). We also found that the adenosine $A_{2 \mathrm{~A}}$ receptor agonist CGS 21680 could not alter neuropathological changes in rat retrosplenial cortex after administration of dizocilpine. Thus, it seems that adenosine $A_{1}$ receptors play a role in the protective effects of CCPA against dizocilpine-induced neurotoxicity.

In the present study, CCPA decreased both the number of vacuolized neurons and the amount of Ach released in the retrosplenial cortex induced by dizocilpine. It has been reported that systemic administration of GABAergic agonists (diazepam and pentobarbital), the $\alpha_{2}$-adrenergic agonist clonidine, and the novel metabotropic glutamate receptor agonist LY 379268 significantly suppressed both dizocilpine-induced neuronal vacuolization and ACh release in the rat retrosplenial cortex (Kim et al, 1999; Okamura et al, in press). Interestingly, local injection of clonidine to the retrosplenial cortex did not reduce extracellular Ach levels or the number of vacuolized neurons, whereas local injection to the basal forebrain, where the majority of the cortical-projecting cholinergic neurons exist, significantly reduced the number of vacuolized neurons (Farber et al, 2002). These results indicate that there are certain pathways that mediate the neurotoxicity to this region. The existence of such complex circuitry is supported by the work of Tomitaka et al (2000), which demonstrated that expression of HSP-70 protein in the rat retrosplenial cortex was induced by bilateral injection of dizocilpine into the anterior thalamus, but was not induced by bilateral injection of dizocilpine into the retrosplenial 
cortex. In the present study, local perfusion of CCPA did not affect extracellular Ach levels. The explanation for this result could be that the adenosine $A_{1}$ receptors with which CCPA interacts to suppress the release of Ach in the retrosplenial cortex do not locate within the retrosplenial cortex, but, rather, in the basal forebrain. Further detailed studies are needed to clarify the mechanism by which CCPA reduces the neurotoxicity of dizocilpine in rat retrosplenial cortex.

Several studies have suggested that adenosine plays a role in the behavioral or physiological effects of dizocilpinetreated rodents (Browne and Welch, 1982; Sills et al, 1999; Dall'Igna et al, 2003). Based on the findings in those reports, a possible state of adenosinergic hypoactivity in schizophrenia has been proposed (Lara, 2002). Furthermore, a clinical study indicated that dipyridamole, an adenosine uptake inhibitor, plus haloperidol is significantly more effective than haloperidol alone for decreasing psychopathological symptoms of patients with schizophrenia (Akhondzadeh et al, 2000), which is in line with the model of adenosine activity-deficit proposed for that disease (Lara, 2002). Those findings, taken with ours here, suggest that adenosine $A_{1}$ receptors may, in part, contribute to the pathophysiology of schizophrenia. The findings obtained here, however, were not in themselves sufficient to conclude that adenosine $A_{1}$ receptor agonists would be effective drugs for schizophrenia.

In conclusion, the results of the present study indicate that adenosine $A_{1}$ receptor agonists significantly decrease neuronal vacuolization and the expression of HSP-70 protein in the rat retrosplenial cortex following administration of the NMDA receptor antagonist dizocilpine. Based on the NMDA hypofunction hypothesis in schizophrenia, our findings suggest that adenosine $\mathrm{A}_{1}$ receptors may play a role in the pathophysiology of schizophrenia.

\section{ACKNOWLEDGEMENTS}

We are grateful to Ms Y Fujita for her technical assistance.

\section{REFERENCES}

Akhondzadeh S, Shasavand E, Jamilian H, Shabestari O, Kamalipour A (2000). Dipyridamole in the treatment of schizophrenia: adenosine-dopamine receptor interactions. J Clin Pharm Ther 25: 131-137.

Brown IR (1995). The stress response. Neuropathol Appl Neurobiol 21: 473-475.

Browne RG, Welch WM (1982). Stereoselective antagonism of phencyclidine's discriminative properties by adenosine receptor agonists. Science 217: 1157-1159.

Coyle JT (1996). The glutamatergic dysfunction hypothesis for schizophrenia. Harv Rev Psychiatry 3: 241-253.

Cunha RA (2001). Adenosine as a neuromodulator and as a homeostatic regulator in the nervous system: different roles, different sources and different receptors. Neurochem Int 38: $107-125$.

Dall'Igna OP, Da Silva AL, Dietrich MO, Hoffmann, de Oliveira RV, Souza DO et al (2003). Chronic treatment with caffeine blunts the hyperlocomotor but not cognitive effects of the $N$-methyl-Daspartate receptor antagonist MK-801 in mice. Psychopharmacology (Berl) 166: 258-263.
Farber NB, Foster J, Duhan NL, Olney JW (1996). Olanzapine and fluperlapine mimic clozapine in preventing MK-801 neurotoxicity. Schizophr Res 21: 33-37.

Farber NB, Kim SH, Dikranian K, Jiang XP, Heinkel C (2002). Receptor mechanisms and circuitry underlying NMDA antagonist neurotoxicity. Mol Psychiatry 7: 32-43.

Farber NB, Wozniak DF, Price MT, Labruyere J, Huss J, St Peter H et al (1995). Age-specific neurotoxicity in the rat associated with NMDA receptor blockade: potential relevance to schizophrenia? Biol Psychiatry 38: 788-796.

Fix AS, Wozniak DF, Truex LL, McEwen M, Miller JP, Olney JW (1995). Quantitative analysis of factors influencing neuronal necrosis induced by MK-801 in the rat posterior cingulate/ retrosplenial cortex. Brain Res 696: 194-204.

Fredholm BB (1995). Purinoceptors in the nervous system. Pharmacol Toxicol 76: 228-239.

Fredholm BB, Ijzerman AP, Jacobson KA, Klotz KN, Linden J (2001). International Union of Pharmacology. XXV. Nomenclature and classification of adenosine receptors. Pharmacol Rev 53: 527-552.

Fujimura M, Hashimoto K, Yamagami K (2000). Effects of antipsychotic drugs on neurotoxicity, expression of fos-like protein and c-fos mRNA in the retrosplenial cortex after administration of dizocilpine. Eur J Pharmacol 398: 1-10.

Gainetdinov RR, Mohn AR, Caron MG (2001). Genetic animal models: focus on schizophrenia. Trends Neurosci 24: 527-533.

Hashimoto K, Fujimura M, Yamagami K (2000). Dizocilpineinduced neuropathological changes in rat retrosplenial cortex are reversed by subsequent clozapine treatment. Life Sci 66: 1071-1078.

Hashimoto K, Tomitaka S, Bi Y, Narita N, Minabe Y, Iyo M (1997). Rolipram, a selective phosphodiesterase type-IV inhibitor, prevents induction of heat shock protein HSP-70 and hsp-70 mRNA in rat retrosplenial cortex by the NMDA receptor antagonist dizocilpine. Eur J Neurosci 9: 1891-1901.

Hashimoto K, Tomitaka S, Narita N, Minabe Y, Iyo M, Fukui S (1996). Induction of heat shock protein (HSP)-70 in posterior cingulated and retrosplenial cortex of rat brain by dizocilpine and phencyclidine: lack of protective effects of $\sigma$ receptor ligands. Addict Biol 1: 61-70.

Jacobson KA, von Lubitz DK, Daly JW, Fredholm BB (1996). Adenosine receptor ligands: differences with acute versus chronic treatment. Trends Pharmacol Sci 17: 108-113.

Javitt DC, Zukin SR (1991). Recent advances in the phencyclidine model of schizophrenia. Am J Psychiatry 148: 1301-1308.

Kim SH, Price MT, Olney JW, Farber NB (1999). Excessive cerebrocortical release of acetylcholine induced by NMDA antagonists is reduced by GABAergic and $\alpha_{2}$ adrenergic agonists. Mol Psychiatry 4: 344-352.

Koek W, Woods JH, Winger GD (1988). MK-801, a proposed noncompetitive antagonist of excitatory amino acid neurotransmission, produces phencyclidine-like behavioral effects in pigeons, rats and rhesus monkeys. J Pharmacol Exp Ther 245: 969-974.

Krystal JH, Karper LP, Seibyl JP, Freeman GK, Delaney R, Bremner JD et al (1994). Subanesthetic effects of the noncompetitive NMDA antagonist, ketamine, in humans. Psychotomimetic, perceptual, cognitive, and neuroendocrine responses. Arch Gen Psychiatry 51: 199-214.

Lara DR (2002). Inhibitory deficit in schizophrenia is not necessarily a GABAergic deficit. Cell Mol Neurobiol 22: 239-247.

Lohse MJ, Klotz KN, Schwabe U, Cristalli G, Vittori S, Grifantini M (1988). 2-Chloro- $N^{6}$-cyclopentyladenosine: a highly selective agonist at A1 adenosine receptors. Naunyn Schmiedebergs Arch Pharmacol 337: 687-689.

Luby ED, Cohen BD, Rosenbaum G, Gottlieb JS, Kelley R (1959). Study of a new schizophrenomimetic drug: Sernyl. Arch Neurol Psychiatry 81: 363-369. 
Matsuki H, Shirayama Y, Hashimoto K, Tanaka A, Minabe Y (2001). Effects of age and gender on the expression of brainderived neurotrophic factor mRNA in rat retrosplenial cortex following administration of dizocilpine. Neuropsychopharmacology 25: 258-266.

Morimoto T, Hashimoto K, Yasumatsu H, Tanaka H, Fujimura M, Kuriyama $M$ et al (2002). Neuropharmacological profile of a novel potential atypical antipsychotic drug Y-931 (8-fluoro-12(4-methylpiperazin-1-yl)- 6H-[1]benzothieno[2,3-b][1,5] benzodiazepine maleate). Neuropsychopharmacology 26: 456-467.

Okamura N, Hashimoto K, Kanahara N, Shimizu E, Kumakiri C, Komatsu $\mathrm{N}$ et al (2003). Protective effect of the antipsychotic drug zotepine on dizocilpine-induced neuropathological changes in rat retrosplenial cortex. Eur J Pharmacol 461: 93-98.

Okamura N, Hashimoto K, Shimizu E, Koike K, Ohgake S, Koizumi $\mathrm{H}$ et al Protective effect of LY379268, a selective group II metabotropic glutamate receptor agonist, on dizocilpine-induced neuropathological changes in rat retrosplenial cortex. Brain Res in press.

Olney JW, Farber NB (1995). Glutamate receptor dysfunction and schizophrenia. Arch Gen Psychiatry 52: 998-1007.

Olney JW, Newcomer JW, Farber NB (1999). NMDA receptor hypofunction model of schizophrenia. J Psychiatr Res 33: 523-533.

Paxinos G, Watson C (1998). The Rat Brain in Stereotaxic Coordinates 4th edn Academic Press: San Diego, CA.

Popoli P, Reggio R, Pezzola A (1997). Adenosine $A_{1}$ and $A_{2}$ receptor agonists significantly prevent the electroencephalographic effects induced by MK-801 in rats. Eur J Pharmacol 333: 143-146.

Sharp FR, Jasper P, Hall J, Noble L, Sagar SM (1991). MK-801 and ketamine induce heat shock protein HSP72 in injured neurons in posterior cingulate and retrosplenial cortex. Ann Neurol 30: 801-809.

Sharp FR, Tomitaka M, Bernaudin M, Tomitaka S (2001). Psychosis: pathological activation of limbic thalamocortical circuits by psychomimetics and schizophrenia? Trends Neurosci 24: $330-334$.

Sills TL, Azampanah A, Fletcher PJ (1999). The adenosine $A_{1}$ receptor agonist $N^{6}$-cyclopentyladenosine blocks the disruptive effect of phencyclidine on prepulse inhibition of the acoustic startle response in the rat. Eur J Pharmacol 369: 325-329.

Stone TW (1991). Receptors for adenosine and adenine nucleotides. Gen Pharmacol 22: 25-31.

Tamminga CA (1998). Schizophrenia and glutamatergic transmission. Crit Rev Neurobiol 12: 21-36.

Tomitaka S, Hashimoto K, Narita N, Sakamoto A, Minabe Y, Tamura A (1996). Memantine induces heat shock protein HSP70 in the posterior cingulated cortex, retrosplenial cortex and dentate gyrus of rat brain. Brain Res 740: 1-5.

Tomitaka S, Tomitaka M, Tolliver BK, Sharp FR (2000). Bilateral blockade of NMDA receptors in anterior thalamus by dizocilpine (MK-801) injures pyramidal neurons in rat retrosplenial cortex. Eur J Neurosci 12: 1420-1430.

Tricklebank MD, Singh L, Oles RJ, Preston C, Iversen SD (1989). The behavioural effects of MK-801: a comparison with antagonists acting non-competitively and competitively at the NMDA receptor. Eur J Pharmacol 167: 127-135.

Von Lubitz DK, Lin RC, Bischofberger N, Beenhakker M, Boyd M, Lipartowska $\mathrm{R}$ et al (1999). Protection against ischemic damage by adenosine amine congener, a potent and selective adenosine $\mathrm{A}_{1}$ receptor agonist. Eur J Pharmacol 369: 313-317. 